VERTAISARVIOITU

KOLLEGIALT GRANSKAD

PEER-REVIEWED

www.tsv.fi/tunnus

\title{
"KUULUUKO TÄÄLTÄ, KUULUUKO NYT?": TOHTORIOPISKELIJOIDEN VERKKOVÄLITTEISEN KIRJOITUSOPETUKSEN ONGELMATILANTEIDEN NEKSUSANALYYSI
}

\author{
Melina Aarnikoivu, Soveltavan kielentutkimuksen keskus, \\ Jyväskylän yliopisto
}

Taina Saarinen, Koulutuksen tutkimuslaitos, Jyväskylän yliopisto

\begin{abstract}
Tässä tutkimuksessa selvitimme, millaisia ongelmatilanteita tohtoriopiskelijoiden monikanavaiseen seminaaritoimintaan sisältyi. Lisäksi tutkimme, millaisia seurauksia tilanteista aiheutui. Tutkimuksen teoreettis. metodologisena viitekehyksenä käytimme neksusanalyysiä (Scollon \& Scollon, 2004). Tutkimusaineistomme koostui tohtoriopiskelijoille järjestettyjen "kirjoitusklinikoiden" aikana tehdyistä etnografisista havainnoista, klinikoissa käytetyn AdobeConnectin välityksellä käydyistä chat-keskusteluista, klinikoihin liittyvistä Yammer-keskusteluista sekä tohtoriopiskelijoille ja ohjaajille suunnatun verkkokyselyn tuloksista. Analyysimme perusteella tunnistimme kolme laajempaa kategoriaa, joihin tutkitun kontekstin ongelmatilanteet liittyivät: teknologia, toimijat ja kieli. Ongelmatilanteet veivät aikaa pois käsiteltävältä asialta, vaikeuttivat osallistumista, estivät sen kokonaan, vaikuttivat osallistumisen mielekkyyteen tai koettuun hyödyllisyyteen ja aiheuttivat muita negatiivisia tuntemuksia osallistujissa. Tutkimus ja sen tulokset siirtävät huomion siihen, mitä tapahtuu, kun haluttu tai odotettu välitteinen sosiaalinen toiminta jostain syystä estyy ja auttaa siten suunnittelemaan sitä, miten monikanavaista seminaaritoimintaa voitaisi tohtoriopinnoissa sekä muussa yliopisto-opetuksessa kehittää.
\end{abstract}

Avainsanat: monikanavainen seminaari, neksusanalyysi, tohtoriopinnot, vuorovaikutusjärjestys

\footnotetext{
Kirjoittajien yhteystiedot:

Melina Aarnikoivu

Taina Saarinen

melina.aarnikoivu@jyu.fi

taina.m.saarinen@jyu.fi
} 


\section{JOHDANTO}

Tohtoriopiskelijoiden polku kohti väitöstilaisuutta ja tohtoroitumista koostuu useista erilaisista prosesseista ja toiminnoista, joiden avulla tohtorikandidaatit kehittävät tutkimustaitojaan ja rakentavat tutkijaidentiteettiään. Näiden prosessien tukemiseksi tohtoriopintoihin kuuluu väitöskirjan lisäksi tyypillisesti myös muita opintoja, joiden sisältö ja suoritustapa vaihtelevat suuresti sekä tohtoriohjelmasta että yliopistosta riippuen. Yksi varsin yleinen tällaisten muiden opintojen suoritusmuoto on seminaaritoiminta, joka voi aihepiiriltään liittyä esimerkiksi kirjoittamiseen, esiintymiseen tai tutkimusmetodeihin. Yleisin osallistumismuoto tällaisissa seminaareissa on edelleen fyysinen läsnäolo, joskin etäopiskelu on vakiinnuttanut paikkansa suomalaisessa korkeakoulutuksessa (Lehtinen \& Nummenmaa, 2012). Seminaaritoimintaa, jossa opiskelijat osallistuvat sekä fyysisesti läsnäolevana että etäyhteyden avulla, on kuitenkin tutkittu melko vähän, eikä tällaiselle toiminnalle ole suomen kielessä vakiintunutta termiä. Tässä tutkimuksessa kutsumme sitä monikanavaiseksi seminaaritoiminnaksi (termistä "monikanavainen" katso luku 2).

Koska erilaiset etäopiskelun muodot yleistyvät jatkuvasti, erilaisia viestintämuotoja ja yhteistyön tapoja yhdistelevää seminaaritoimintaa olisi tärkeä ymmärtää yhä paremmin. Tässä tutkimuksessa luomme neksusanalyyttistä viitekehystä (Scollon \& Scollon, 2004) käyttäen katsauksen siihen, millaisia ongelmatilanteita tohtoriopiskelijoille suunnattuun monikanavaiseen seminaaritoimintaan sisältyy. Ongelmatilanteiden aiheuttajien lisäksi tarkastelemme sitä, mitä tapahtuu sen jälkeen, kun suunniteltu tai odotettu toiminta erilaisten tekijöiden vuoksi estyy. Tutkimuksemme empiirisenä kontekstina on Jyväskylän yliopiston Soveltavan kielentutki- muksen keskuksen (tästä eteenpäin 'Solki') kirjoitusklinikat, jotka ovat tohtoriopiskelijoiden kirjoittamisen kehitykseen keskittyviä säännöllisiä tohtoriseminaareja. Tutkimuskysymyksemme ovat:

1) Mitkä tekijät aiheuttivat ongelmatilanteita totuttuun tai odotettuun vuorovaikutusjärjestykseen kirjoitusklinikoissa?

\section{2) Mitä ongelmatilanteista seurasi?}

Aineistomme analyysin pääasiallisina teoreettisina käsitteinä käytämme vuorovaikutusjärjestystä (engl. interaction order) (Goffman, 1983; Scollon \& Scollon, 2004) sekä välitteisen diskurssin analyysiä (engl.mediated discourse analysis) (Norris \& Jones, 2005; Scollon, 2001), joskin sivuamme analyysissämme myös kahta muuta neksusanalyyttistä, sosiaalista toimintaa jäsentävää käsitettä eli toimijahistorioita (historical body) ja paikan diskursseja (discourses in place) (Scollon \& Scollon 2004). Tutkimusaineistomme koostuu kolmentoista Solkin kirjoitusklinikan aikana tehdyistä etnografisista havainnoista, klinikoissa käytetyn AdobeConnectin välityksellä käydyistä chat-keskusteluista, klinikkatoimintaa edeltävistä ja sitä seuraavista Yammer-yhteisöpalvelussa käydyistä keskusteluista sekä klinikkatoimintaa kartoittavan verkkokyselyn avoimista vastauksista.

\section{VERKKO-JA TEKNOLOGIS- VÄLITTEINEN VIESTINTÄ KORKEAKOULUKONTEKSTISSA}

Tutkimuksessamme yhdistyvät useat välitteisen sosiaalisen toiminnan (Scollon \& Scollon, 2004) muodot, joista tärkeimmät tutkimuksen kontekstin näkökulmasta ovat verkkovälitteinen viestintä (erityisesti videokonferenssit) sekä tohtoriopiskelijoiden ohjaus (erityisesti kirjoitustaitojen kehittä- 
minen ja tukeminen). Näistä molempia on tutkittu yksittäisinä ilmiöinä varsin runsaasti. Verkko- ja teknologisvälitteistä viestintää on korkeakoulukontekstissa tutkittu lähinnä oppimisen, oppimiskokemusten ja yhteistyön näkökulmasta (ks. esim. Çakıroğlu, Kokoç, Kol \& Turan, 2016; Kauffmann \& Frisby, 2013; Messina Dahlberg \& Bagga-Gupta, 2014; Wang, Jaeger, Liu, Guo \& Xie, 2013). Näissä tutkimuksissa etäosallistuminen voi tarkoittaa sekä reaaliaikaista että ei-reaaliaikaista viestintää, mutta tämän tutkimuksen kannalta näistä tärkeämpi on reaaliaikainen viestintä, esimerkiksi videokonferenssit.

Videokonferenssien järjestämiseen on nykyisin tarjolla useita ohjelmia, kuten AdobeConnect, Microsoft Teams, Zoom, BlueJeans ja Lifesize. Videokonferenssien opetuskäyttöä koskevien tutkimusten tulokset ovat ristiriitaisia. Esimerkiksi Candarlin ja Yukselin (2012) tutkimuksen mukaan korkeakouluopiskelijoiden asenteet videokonferenssin käyttöä kohtaan opetuksessa olivat varsin negatiiviset. Gilliesin (2008) tutkimuksessa videokonferenssit saivat opiskelijoilta kritiikkiä muun muassa teknisten ongelmien vuoksi, joskin he näkivät videokonferenssien käytössä potentiaalia. Sen sijaan Doggetin (2008) tutkimuksen mukaan neljä viidestä opiskelijasta suhtautui myönteisesti videokonferenssien käyttöön opetuksessa - joskin he olivat sitä mieltä, että perinteinen luokkahuoneasetelma oli parempi. Positiivinen oli myös Allenin, Bourhisin, Burrellin ja Mabryn (2002) toteuttama useamman empiirisen tutkimuksen meta-analyysi, joka paljasti, että etäopetus ei vähentänyt opiskelijoiden tyytyväisyyttä verrattuna normaaliin, kasvokkain tapahtuvaan opetukseen.

Erityisesti tohtoriopiskelijoiden verkkoopetusta tai -oppimista ei juurikaan ole tutkittu (Candela ym., 2008). Zhao, Lei, Yan, Lai ja Tan (2005) ovat esittäneet, että etäopetus itse asiassa soveltuu parhaiten alempaan, mutta ei välttämättä enää ylempään yliopistotutkintoon, joka yleensä vaatii enemmän luovaa ja kriittistä ajattelua. Yksi tohtorikoulutuksen ja etäopetuksen käyttöä koskeva tutkimus on Rosethin, Akcaoglun ja Zellnerin (2013) tapaustutkimus, joka koski vapaasti saatavilla olevien teknologioiden (kuten WordPress) käyttöä yhteistoiminnallisessa pienryhmäoppimisessa, kuten tämän tutkimuksen kaltaisessa monikanavaisessa tohtoriseminaarissa. Roseth ym. kutsuivat tällaista seminaaria termillä "hybrid doctoral seminar". Tapaustutkimuksensa perusteella he suosittelivat, että seminaarien suunnittelu tulisi aloittaa 2-3 kuukautta ennen ensimmäistä tapaamista. Lisäksi sen toteuttavalla tiimillä tulisi olla monipuoliset taidot (teoreettiset, käytännön, ja teknologiset taidot), jotta seminaari onnistuisi. "Hybrid"-termiä ovat käyttäneet myös Henriksen, Mishra, Greenhow, Cain ja Roseth (2014), mutta yksittäisen seminaarin sijaan he käyttivät termiä viittaamaan kokonaiseen tohtoriohjelmaan (engl. "hybrid doctoral program"). Tätä tutkimusta varten suomensimme tällaisen toiminnan "monikanavaiseksi", sillä se kuvaa tutkimaamme toimintaa mielestämme paremmin kuin "hybridiseminaari".

Muita videokonferenssin onnistumisen kannalta olennaisia tekijöitä on tutkittu olevan opettajien pitkäaikaisen osaamisen kehittämisen, opiskelijoiden riittävän valmistautumisen (Andrews \& Klease, 1998) ja riittävän ajan sekä rahan (Dogget, 2008; Martin, 2005). Videokonferenssitoiminnan lisäksi tämän tutkimuksen kannalta on tärkeää tarkastella myös kirjoittamista ja siihen saatua tukea. Seuraavaksi luomme tiiviin katsauksen siihen, mikä aiempien tutkimusten mukaan on oleellista tohtoriopiskelijoiden kirjoittamisen tukemisessa. 


\section{TOHTORIOPISKELIJOIDEN KIRJOITTAMISEN TUKEMINEN}

Yksi tärkeimmistä tohtoriopintoihin liittyvistä toiminnoista on kirjoittaminen (Cotterall, 2011; Ferguson, 2009; Kamler \& Thomson, 2006). Yliopistot tarjoavatkin usein monipuolista tukea akateemiseen kirjoittamiseen. Kirjoittamiskurssit eivät sellaisenaan yleensä kuitenkaan kuulu pakollisiin tohtoriopintoihin, joskin tilanne on Suomessa hiljalleen muuttumassa ohjauksen ja muiden tohtorintutkintoon kuuluvien kurssien saadessa opetussuunnitelmissa yhä enemmän huomiota. Esimerkiksi Delyser (2003) on esittänyt, että vaikka tohtoriopiskelijat saavat hyvät valmiudet tutkimuksensa tekemiseen, he eivät saa tarpeeksi valmiuksia tutkimustulostensa esittämiseen ja niistä viestimiseen. Samaa mieltä ovat myös Kamler (2008) ja Piattoeva (2016), joiden mukaan kirjallista ilmaisua painotetaan tohtorikoulutuksessa edelleen liian vähän huolimatta siitä, että akateeminen maailma nimenomaan korostaa julkaisujen ja tutkimustulosten levittämisen merkitystä. Akateemisten kirjoitustaitojen kehityksellä ei siis ole merkitystä vain yksilö-, vaan myös yliopistotasolla (Murray, 2001).

Vaikka tohtoriopiskelijoiden kirjoittamista on tutkittu paljon (ks. esim. Ferguson, 2009; Lee \& Boud, 2003; Maher ym., 2008; Morss \& Murray, 2001), tutkimus on keskittynyt lähinnä siihen, mitä tapahtuu, kun osallistujat jo ovat toiminnan keskiössä. On siis jäänyt vähemmälle huomiolle, mikä tällaisen toiminnan ylipäätään mahdollistaa ja mitkä sen rajat ovat. Muutamana poikkeuksena ovat esimerkiksi Johnsonin (2014), Lassigin, Dillonin ja Diezmannin (2013), Maherin, Falluccan ja Halaszin (2013) sekä Suomen kontekstissa tosin maisteriopiskelijoita koskien - Svinhufvudin (2014) tutkimukset. Näissä mainitaan opiskelijat, jotka päättivät olla osallistumatta kirjoitustapaamisiin, osallistujien vaikeudet löytää sopivia tapaamisaikoja, tai osallistujien haluttomuus osallistua yhteiseen keskusteluun ja siihen vaikuttavat tekijät. Näistä laajimman huomion erilaisille kirjoitusopetuksen esteille, kuten esimerkiksi ajan ja tilan rajoitteille, antavat Maher ym. (2013), jotka painottavat tulostensa raportoinnissa sitä, miten kirjoitusryhmät olivat kiireisille tutkijoille suojattua aikaa suojatussa tilassa ("protected time and space", Maher ym., 2013, s. 200). Samaisessa tutkimuksessa mainitaan hyvin lyhyesti myös osa-aikaiset opiskelijat, jotka eivät välttämättä asu lähellä yliopistoa.

Tässä tutkimuksessa haluamme nimenomaan keskittyä yllä kuvaillun kaltaisen toiminnan rajoitteisiin, joita tässä tutkimuksessa kutsumme ongelmatilanteiksi. Näiden analysoimiseksi olemme valinneet tutkimuksemme teoreettis-metodologiseksi viitekehykseksi neksusanalyysin (Scollon \& Scollon, 2004, 2007), jonka peruskäsitteet esittelemme seuraavaksi.

\section{TOHTORISEMINAARIT SOSIAALISENA, DISKURSIIVISENA SEKÄ VÄLITTEISENÄ TOIMINTANA: NEKSUSANALYYSIN PERUSKÄSITTEET}

Tutkimuksemme teoreettis-metodologisena viitekehyksenä toimii erilaisia metodologioita ja metodeja yhdistelevä neksusanalyysi (Scollon \& Scollon, 2004). Neksusanalyysi keskittyy sosiaaliseen toimintaan, erilaisiin semioottisiin resursseihin, eli niihin resursseihin, joiden avulla luomme merkitystä vuorovaikutuksessa (Kress, 2010; Scollon \& Scollon, 2004), sekä näiden välisiin suhteisiin. Sen tarkoitus on valottaa erilaisten sosiaalisten ilmiöiden luonnetta tarkastelemalla tutkittavan ilmiön eri osioiden suhdetta sekä toisiinsa että varsinaiseen ilmiöön. Esimerkiksi tässä tutkimuksessa se tarkoittaa sitä, 
miten yksittäisen tohtoriseminaarin tapahtumat (tekstistä keskustelu tai etäyhteyden katkeaminen) kytkeytyvät toisiinsa, mutta samalla myös laajemmin tohtoriopiskelijan kirjoittamisen kehitykseen.

Neksusanalyysin periaatteiden mukaisesti toistuvasti tapahtuvaa sosiaalista toimintaa voidaan kutsua sosiaaliseksikäytänteeksi (social practice), jossa 1) vuorovaikutusjärjestys (interaction order), 2) paikan diskurssit (discourses in place) sekä 3) toimijabistoriat (historical bodies) ${ }^{1}$ kietoutuvat toisiinsa. Näitä kolmea sosiaalisen toiminnan ulottuvuutta kartoittamalla tutkija kykenee sukeltamaan tutkittavan ilmiön pinnan alle ja muodostamaan tutkimuskysymykset sitä kautta. (Scollon \& Scollon, 2004.) Tämän tutkimuksen kannalta hedelmällisin näistä kolmesta käsitteestä on ensimmäinen, vuorovaikutusjärjestys. Se viittaa siihen, miten vuorovaikutus järjestäytyy ja miten toimijat luovat sen yhdessä eri tilanteissa. Goffmanin (1983) mukaan eri tilanteissa on mukana erilaisia historiallisesti rakentuneita normeja ja odotuksia sekä jokaisen toimijan omat kulttuuriset odotukset ja kokemukset aiemmista vuorovaikutustilanteista. Paikan diskurssit puolestaan viittaavat niihin sosiaalisiin käytänteisiin, kieleen ja objekteihin, jotka ovat tutkittavan ilmiön

\footnotetext{
1 Näistä kolmesta sosiaalisen toiminnan osa-alueesta ainoastaan vuorovaikutusjärjestys on suomen kielessä jokseenkin vakiintunut. Historical body -käsitteelle on esitetty suomennokseksi toimijahistoriaa (Rautiainen-Keskustalo ym., 2014), historiallista elämäkertaa (Pietikäinen, 2012), toimijan elämänhistoriaa (Karjalainen, 2015), elämänhistoriaa (Virtanen, 2017) sekä toimijan elämänhistoriaa (Strömmer, 2017). Discourses in place -käsitteelle on puolestaan tarjottu suomennokseksi mm. paikan diskursseja (Rautiainen-Keskustalo ym., 2014), diskursseja (Pietikäinen, 2012; Strömmer, 2017), sekä tilanteisia diskursseja (Virtanen, 2017). Valitsimme toimijahistorian samoin perustein kuin RautiainenKeskustalo ym. (ks. 2014, s. 21). Paikan diskurssit puolestaan valitsimme käännökseksi siitä syystä, että diskurssit ovat riippuvaisia tietystä tilanteesta ja paikasta. Tästä näkökulmasta tilanteiset diskurssit olisi aivan yhtä hyvä käännös. Valitsimme näistä kuitenkin kirjaimellisemman käännöksen.
}

kannalta olennaisimpia (Scollon \& Scollon, 2004). Viimeinen, toimijahistoriat, viittaa sosiaalisen toiminnan keskiössä olevien toimijoiden fyysiseen kehoon ja sen historiaan, mutta myös toimijoiden erilaisiin rooleihin ja siihen, miten esimerkiksi heidän henkilökohtaiset kokemuksensa, tavoitteensa ja motivaationsa vaikuttavat toimintaan.

Esimerkiksi vaikkapa säännölliseen kirjoitustyöpajaan osallistuvilla sekä niitä järjestävillä toimijoilla on erilaisia, aiempaan kokemukseen, järjestäjiltä saatuihin tietoihin tai muilta osallistujilta kuultuihin kokemuksiin perustuvia odotuksia siitä, mitä kirjoitustyöpajassa tapahtuu ja miten ja mistä siellä keskustellaan. Nämä normit ovat sitä tutumpia, mitä useammin kukin toimija on vastaavanlaiseen tilanteeseen osallistunut. Koska Scollon ja Scollon (2004) laajentavat Goffmanin (1983) vuorovaikutusjärjestyksen käsitteen koskemaan kasvokkaisviestinnän lisäksi myös teknologian kautta tapahtuvaa viestintää, tutkijan tulisi kiinnittää huomio myös siihen, miten teknologiaa käytetään. Lisäksi on tärkeä huomioida, miten toimijat tilassa liikkuvat tai miten he tilaan asettautuvat; esimerkiksi onko joku puheenjohtajamaisessa roolissa, missä mahdollinen puheenjohtaja tai puhujat istuvat tai seisovat ja niin edelleen.

Tällaiseen välitteiseen toimintaan (esim. Wertsch, 1998) liittyy tutkimuksemme toinen teoreettinen, vuorovaikutusjärjestystä laajempi käsite, välitteinen diskurssianalyysi (engl.mediated discourse analysis). Välitteinen diskurssianalyysi on neksusanalyysin taustalla vaikuttava diskurssintutkimuksen suuntaus, joka laajentaa diskurssien tutkimuksen koskemaan tekstien analyysin lisäksi myös toiminnan, kulttuuristen työkalujen sekä toiminnan sosiaalisten seurausten analyysiä (Norris \& Jones, 2005). Tämäkään analyysisuuntaus ei kuitenkaan ole syntynyt tyhästä, vaan se on saanut vaikutteita Vygotskyn $(1978,1987)$ ja myöhemmin Wertschin sekä 
hänen kollegoidensa työstä (ks. Penuel \& Wertsch, 1995; Wertsch, 1991, 1995, 1998). Välitteisen diskurssianalyysin tausta-ajatuksena on se, että toiminta materialisoituu toimijoissa ja objekteissa (Scollon, 2001), kuten esimerkiksi teknologiassa. Siispä välitteisen diskurssianalyysin periaatteiden mukaisesti ymmärryksemme tietystä sosiaalisesta tilanteesta kasvaa merkittävästi, mikäli laajennamme analyysiä pelkkien tekstien ulkopuolelle (Norris \& Jones, 2005). Välitteisen diskurssianalyysin kohteena on siis erilainen välitteinen toiminta (engl. mediated action), joka Wertschin (1998) mukaan keskittyy kahteen elementtiin: toimijaan (agent) ja välittäjään (mediational means), joiden välillä on jatkuva jännite. Tämä on seurausta siitä, että jokaisella välittäjällä on oma historiansa ja käyttötarkoituksensa. Eri välittäjät voivat siis mahdollistaa tai rajoittaa tiettyjä toimintoja. (Jones \& Norris, 2005).

Vaikka sosiaalisen toiminnan kaikki osaalueet (vuorovaikutusjärjestys, paikan diskurssit ja toimijahistoria) kuuluvat olennaisena osana neksusanalyysiin, emme tämän tutkimuksen rajoissa voineet analysoida kaikkia yhtä laajasti. Tutkittavan toiminnan luonteen vuoksi olemme valinneet pääasialliseksi analyysin kohteeksi vuorovaikutusjärjestyksen. Viittaamme tulosten raportoinnissa kuitenkin myös paikan diskursseihin ja toimijahistorioihin osoittaaksemme, kuinka nämä kolme ovat kytköksissä toisiinsa ja tutkittavaan seminaaritoimintaan laajemmin.

\section{SOLKIN KIRJOITUSKLINIKKA JA SEN VUOROVAIKUTUS- JÄRJESTYKSEN NORMIT}

Tekeillä olevassa väitöskirjassaan Aarnikoivu, toinen kirjoittajista, tarkastelee tohtoriopiskelijoiden polkua sosiaalisen toiminnan näkökulmasta neksusanalyyttistä lähestymistapaa käyttäen. Tutkimustaan varten hän keräsi osan aineistostaan Solkissa, Jyväskylän yliopistossa tammikuun 2016 ja toukokuun 2017 välillä. Solki on erikoistunut tarkastelemaan kielikoulutuksen tavoitteita, käytänteitä ja politiikkaa ja sen tutkimuksen painoalat ovat kielitaidon arviointi, kielitaidon kehittyminen erilaisissa konteksteissa ja toimintayhteisöissä, sekä kielikoulutuspolitiikka. Keskuksessa on kaikkiaan noin 50 tohtoriopiskelijaa. Vain noin joka neljäs tohtoriopiskelija tekee väitöskirjaansa päätoimisesti joko yliopiston tai jonkun säätiön rahoituksella. Sivutoimisten tohtoriopiskelijoiden joukko onkin Solkin tohtorituotannon näkökulmasta merkittävä: suurin osa viime vuosien väitöskirjoista on valmistunut vähintään osittain työn ohessa, sivutoimisena ja käytännössä etänä. Työelämästä väitöskirjan tekijöiksi lähteneillä on myös kulunut jo jonkin aikaa edellisistä akateemisen kirjoittamisen kokemuksista. Etäopiskelijoiden määrää lisää myös Solkin rekrytointipohjan laajuus: Solkin kansallinen erityistehtävä erityisesti kielitaidon arvioinnissa ja kielikoulutuspolitiikassa laajentaa tohtoriopiskelijoiden rekrytointipohjan Jyväskylän ulkopuolelle, ja viime vuosina kansainvälisten tohtoriopiskelijoiden määrä on lisääntynyt selvästi.

Kirjoitusklinikkatoimintaa alettiin kehittää vuoden 2014 lopulla. Alun perin tavoitteena oli edistää etänä ja osa-aikaisesti opiskelevien integroitumista tutkijayhteisöön, mutta pian huomattiin, että kokoaikaisesti ja fyysisesti paikan päällä opiskelevilla oli samat tarpeet. Perinteisten tutkimusseminaarien järjestämistä jatkettiin samalla, mutta kirjoitusklinikat haluttiin pitää mahdollisimman matalan kynnyksen tapahtumina, joissa voitiin käsitellä jatko-opiskelua epämuodollisestikin. Solkin niin sanottu minipooli eli tuolloisen pedagogisen johtajan (tämän artikkelin kirjoittaja Saarinen) tueksi perustettu työryhmä sai parina vuonna tiedekunnalta rahoitusta, jolla hankittiin koulutusta ohjaajille ja tarvittavat välineet verkkoseminaareihin. 
Kirjoitusklinikoissa käsitellään ${ }^{2}$ kerrallaan joko yhden tai kahden tohtoriopiskelijan sen hetkistä kirjoitusprojektia (esim. artikkelia, artikkelin tai monografian osaa, tutkimussuunnitelmaa tai rahoitushakemusta). Klinikan aiheena voi myös olla jokin yleinen kirjoittamisen ilmiö, kuten esimerkiksi artikkeliväitöskirjan yhteenveto, yhteiskirjoittaminen tai tieteidenvälisen tutkimuksen tekeminen. Klinikoissa on myös käyty läpi esitarkastus- ja väitösprosessia. Tarkoituksena on siis ennen kaikkea pubua kirjoittamisesta ja teksteistä, ei kirjoittaa. Varsinaisen kirjoittamisen on tarkoitus tapahtua ennen klinikkatapaamista ja sen jälkeen.

Vaikka kirjoitusklinikka on käsiteltävien tekstien osalta melko joustava, vuosien myötä klinikkatoiminta on vakiintunut tietynlaiseksi, ja sitä koskevat tietyt vuorovaikutusjärjestykseen liittyvät säännöt, jotka tulevat esille esimerkiksi klinikkakerroista muistuttavissa sähköposteissa. Klinikkatapaamisia varten tulee yleensä valmistautua. Mikäli tapaamisessa käsitellään tohtoriopiskelijan artikkelia tai sen osaa, hän lähettää tekstin tai muun materiaalin etukäteen Solkin tohtoriopiskelijoiden omaan Yammer-yhteisöpalveluryhmään viimeistään kahta päivää ennen klinikkatapaamista. Klinikkaan osallistuvat voivat ladata tekstin Yammerista, lukea sen etukäteen ja kirjoittaa ylös kommentteja, jotka he antavat kirjoittajalle klinikassa. Joskus kirjoittaja saa kommentteja etukäteen sähköpostitse. Toisinaan myös ne, jotka eivät pääse osallistumaan klinikkatapaamiseen, lähettävät kirjoittajalle omat kommenttinsa sähköpostitse. Mikäli viittomakielen tulkit osallistuvat tapahtu-

\footnotetext{
2 Vuonna 2019 kirjoitusklinikat yhdistettiin virallisesti muuhun Solkin tohtoriseminaaritoimintaan, jolloin myös "kirjoitusklinikka"-nimestä luovuttiin ja Yammer-yhteisöpalvelu ja AdobeConnect vaihtuivat Microsoft Teams-sovellukseen. Kirjoitustapaamisten toimintaperiaatteet kuitenkin säilyivät samoina, minkä vuoksi käytämme tässä artikkelissa selvyyden vuoksi preesens-aikamuotoa kirjoitusklinikoista puhuttaessa.
}

maan, myös he voivat ladata Yammerista tekstit ja materiaalit etukäteen valmistuakseen tulkkaukseen.

Tapaamiset kestävät puolitoista tuntia, ja niihin on mahdollista osallistua joko paikan päällä Solkissa tai etäyhteyden avulla. Etäyhteyden muodostamisessa käytettiin aineistonkeruun aikaan AdobeConnect -ohjelmaa, joka mahdollistaa sekä ääni- että videoyhteyden osallistujien välillä. AdobeConnect -huoneella on aina yksi tai kaksi ylläpitäjän roolissa olevaa henkilöä, jotka varmistavat sekä varttia ennen klinikkaa että sen aikana, että mikrofonit sekä muu tekniikka toimivat. Tilaisuus on suunnattu lähinnä tohtoriopiskelijoille, mutta teemasta riippuen siihen osallistuu myös muuta Solkin väkeä, kuten jo väitellyttä tutkimushenkilökuntaa, etenkin väitöskirjan ohjaajia. Klinikan kieli sovitaan jokaisen session alussa, ja se on aina joko suomi tai englanti. Paikalla on myös tarvittaessa kaksi viittomakielen tulkkia. Lukuvuonna 2016-2017 kirjoitusklinikoita järjestettiin kolmen viikon välein, yhteensä 10 kappaletta. Yksittäisten kirjoitusklinikoiden osallistujamäärä vaihteli muutamasta lähes kahteenkymmeneen.

\section{TUTKIMUSAINEISTO JA -METODIT}

Neksusanalyysiin kuuluu olennaisena osana niin sanottu navigointi, jonka tarkoituksena on löytää tutkittavan ilmiön kannalta olennaiset toimijat, tapahtumat, diskurssit ja objektit. Tohtoriopintoja koskevaa väitöskirjaaineistoa kerätessään Aarnikoivu huomasi, miten olennainen ja tärkeä osa tohtoriopintoja säännöllisesti järjestettävät kirjoitusklinikat Solkissa olivat. Koska Aarnikoivu havainnoi useimpia klinikoita etäosallistujana, hänen huomionsa kiinnittyi erityisesti siihen, miten teknologia (esim. tietokoneet, videokonferenssialusta AdobeConnect, äänentoistolaitteet, Yammer-yhteisöpalvelu) 
sekä mahdollisti että rajoitti niiden tohtoriopiskelijoiden (tai ohjaajien) osallistumista, jotka eivät olleet fyysisesti seminaaritilassa. Kuten neksusanalyysin periaatteisiin (Scollon \& Scollon, 2004) kuuluu, tämä huomio puolestaan määritteli Aarnikoivun myöhempää aineistonkeruuta. Hänen tekemiensä havaintojen motivoimana päätimme myös toteuttaa tämän tutkimuksen.

Koska Aarnikoivun tekemät kenttähavainnot olivat osa laajempaa väitöskirjatutkimusta, niissä keskityttiin kirjoitusklinikkatoiminnan lisäksi myös muihin tohtoriopintoja koskeviin teemoihin. Saadaksemme vastaukset tässä artikkelissa esitettyihin tutkimuskysymyksiin irrotimme Aarnikoivun keräämästä laajasta aineistosta kirjoitusklinikkaa koskevat osuudet: kolmentoista eri klinikkatapaamisen kenttähavainnot, AdobeConnect -chat-keskustelut sekä jokaista tapaamista edeltävät ja seuraavat Yammer-keskustelut (välillä tammikuu 2016-toukokuu 2017). Lisäksi laadimme tätä tutkimusta varten myös kirjoitusklinikkaa koskevan verkkokyselyn (Webropol), joka lähetettiin sähköpostilinkillä kaikille Solkin 85:lle sen hetkiselle tohtoriopiskelijalle ja ohjaajalle huhtikuussa 2017. Heistä kyselyyn vastasi 30 . Verkkokyselyssä oli kahdeksan kysymystä ja ne olivat sekä suomeksi että englanniksi. Kysymykset sisälsivät neljä vastaajien taustatietoja ja klinikkaan osallistumista kartoittavaa monivalintakysymystä sekä neljä klinikan hyötyjä, haittoja ja kehittämistä koskevaa avointa kysymystä. Kyselyyn vastaaminen oli anonyymiä.

Neksusanalyysille tyypillistä on varsin monipolvinen analyysiprosessi, joka usein alkaa jo aineistonkeruuvaiheessa - niin myös tässä tutkimuksessa, kuten aiemmin tässä luvussa olemme kuvanneet. Ennen tämän tutkimuksen tarkempaa analyysiä olimme siis jo käyneet aineistoa läpi monesta eri näkökulmasta, päätyen lopulta johdannossa esitettyihin kahteen tutkimuskysymykseen. Jotta analyysi olisi mahdollisimman systemaattinen, toteutimme analyysin kahdessa vaiheessa. Ensimmäistä tutkimuskysymystä varten (ongelmatilanteiden aiheuttajat) kävimme koko aineiston läpi induktiivisella sisällönanalyysillä (esim. Hsieh \& Shannon, 2005; Mayring, 2000). Toista tutkimuskysymystä varten (ongelmatilanteiden seuraukset) sen sijaan tarkastelimme sisällönanalyysin paljastamia tilanteita välitteisen diskurssianalyysin sekä vuorovaikutusjärjestyksen näkökulmasta. Havainnollistamme analyysiprosessin kulkua ohessa olevasta taulukosta löytyvien kahden aineistoesimerkin avulla: 
TAULUKKO 1. Aineiston analyysiprosessi.

\begin{tabular}{|c|c|c|}
\hline Aineistoesimerkki & $\begin{array}{l}\text { 1. tutkimuskysymys } \\
\text { (sisällönanalyysi, } \\
\text { olennaiset kohdat } \\
\text { alleviivattu): } \\
\text { Mitkä tekijät aiheut- } \\
\text { tivat ongelmatilan- } \\
\text { teita totuttuun tai } \\
\text { odotettuun vuorovai- } \\
\text { kutusjärjestykseen } \\
\text { kirjoitusklinikoissa? }\end{array}$ & $\begin{array}{l}\text { 2. tutkimuskysymys } \\
\text { (näkökulma: } \\
\text { välitteinen diskurssi- } \\
\text { analyysi, vuorovaiku- } \\
\text { tusjärjestys, olennai- } \\
\text { set kohdat lihavoitu): } \\
\text { Mitä ongelma- } \\
\text { tilanteista seurasi? }\end{array}$ \\
\hline 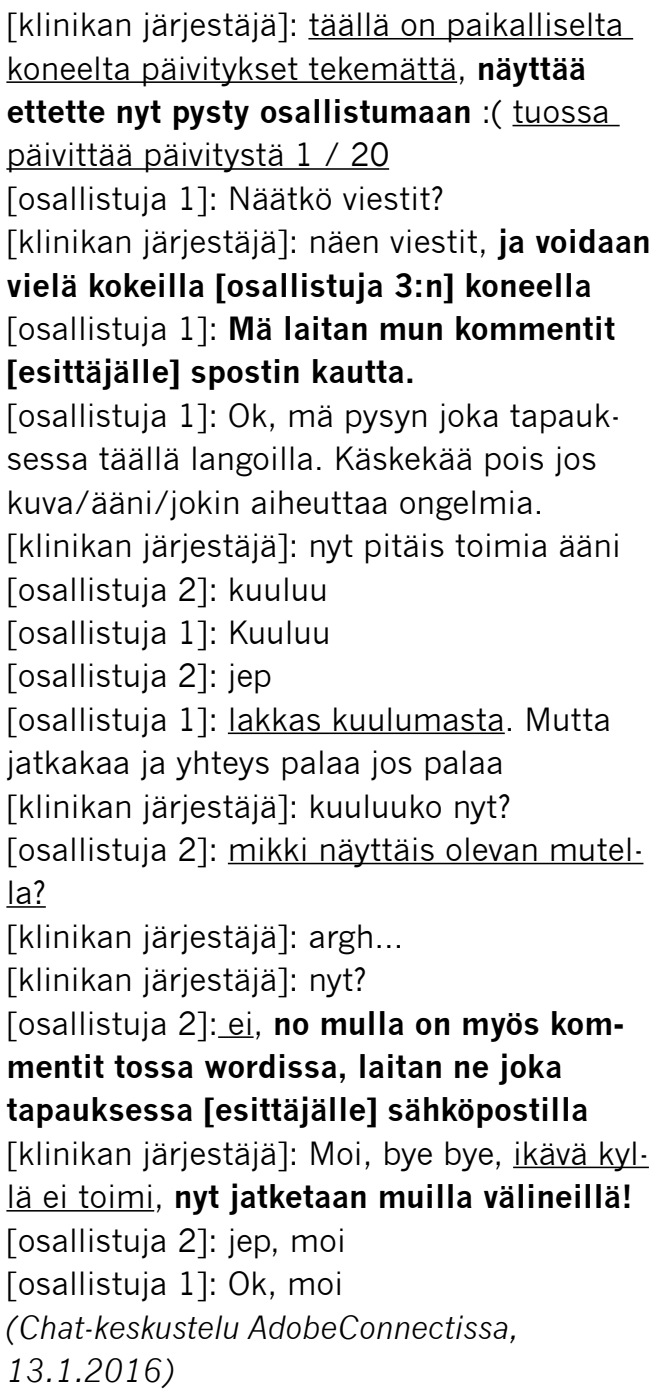 & $\begin{array}{l}\text { Tämä esimerkki } \\
\text { on ote erään } \\
\text { kirjoitusklinikan } \\
\text { alussa käydystä } \\
\text { AdobeConnect } \\
\text { chat-keskustelusta. } \\
\text { Tässä klinikassa } \\
\text { etäosallistujia oli } \\
\text { kaksi (osallistujat } \\
1 \text { ja 2). Klinikan } \\
\text { aluksi klinikan } \\
\text { järjestäjä ilmoittaa, } \\
\text { että seminaaritilan } \\
\text { konetta ei ole päivi- } \\
\text { tetty. Tämä on sekä } \\
\text { teknologiaan liitty- } \\
\text { vä ongelma, mutta } \\
\text { toisaalta myös } \\
\text { toimijoihin liittyvä } \\
\text { ongelma, sillä } \\
\text { päivitykset olisi } \\
\text { mahdollista tarkas- } \\
\text { taa ja tehdä etukä- } \\
\text { teen. Lopulta kone } \\
\text { päivittyy, mutta } \\
\text { teknologiaongelmat } \\
\text { jatkuvat: ääniyhteys } \\
\text { seminaaritilasta } \\
\text { etäosallistujille ei } \\
\text { toimi. }\end{array}$ & $\begin{array}{l}\text { Tässä esimerkissä } \\
\text { teknologiaan ja } \\
\text { toimijoihin liittyvät } \\
\text { ongelmat aiheutta- } \\
\text { vat ensiksi klinikan } \\
\text { viivästymisen. Päivi- } \\
\text { tysten valmistumisen } \\
\text { jälkeen teknologiaa } \\
\text { (tässä tapauksessa } \\
\text { ääniyhteyttä) ei } \\
\text { kuitenkaan edelleen } \\
\text { saada toimimaan. } \\
\text { Tämä aiheuttaa sen, } \\
\text { että etäosallistujat } \\
\text { eivät voi lainkaan } \\
\text { osallistua. Sen sijaan } \\
\text { he lähettävät esittä- } \\
\text { jälle kommenttinsa } \\
\text { sähköpostitse. }\end{array}$ \\
\hline
\end{tabular}

Kävimme koko aineiston läpi yllä olevan taulukon kuvaamalla tavalla. Tämän jälkeen järjestimme ensimmäisen tutkimuskysymysten löydökset kolmeksi laajemmaksi temaattiseksi kategoriaksi. Nämä kolme kategoriaa sekä niistä kuhunkin liittyvät seuraukset esittelemme seuraavaksi tulososiossa. 
7 TULOKSET:

KIRJOITUSKLINIKAN

ONGELMATILANTEET JA NIIDEN SEURAUKSET

Analyysimme perusteella tekijät, jotka aiheuttivat ongelmatilanteita kirjoitusklinikoiden vuorovaikutusjärjestykseen, voidaan jaotella kolmeen laajempaan kategoriaan: 1) teknologia, 2) toimijoihin liittyvät tekijät sekä 3) kieleen liittyvät tekijät. Haluamme kiinnittää huomion siihen, mitä ongelmatilanteiden aikana ja jälkeen tapahtuu ja miten se vaikuttaa klinikkatoimintaan. Tässä luvussa analysoimme tulokset kategorioittain.

\subsection{Teknologia}

[klinikan järjestäjä]: moi [osallistuja 1]

[osallistuja 1]: moi!

[klinikan järjestäjä]: kuuluuko täältä?

[osallistuja 1]: ei

[klinikan järjestäjä]: kuuluukos nyt

[osallistuja 1]: ei

[klinikan järjestäjä]: kuuluuko nyt

[osallistuja 1]: no nyt ilmestyi mikrofonin kuva tuonne sun nimen viereen ja kuuluu jotain kaukaista muminaa

[osallistuja 1]: joo kuuluu vähäsen, ehkä vähän volyymejä voisi nostaa?

(AdobeConnect -chat-keskustelu, kirjoitusklinikka 13.1.2016)

Yllä oleva aineistoesimerkki kuvaa hyvin sitä tapaa, jolla useimmat tutkimusta varten havainnoiduista kirjoitusklinikoista alkoivat. Joskus tämänkaltainen keskustelu kesti pari minuuttia, toisinaan taas paljon pidempään. Kategorioista ensimmäinen, teknologia, sisältää siis erilaiset teknologiaan ja sen käyttöön liittyvät ongelmat, joista yleisin liittyi ääniyhteyteen: joko etäosallistujat eivät kuulleet seminaaritilassa olevia osallistujia (tai toi- sin päin) lainkaan, tai kuuluvuus seminaaritilasta etäosallistujien suuntaan oli huono tai pätkivä. Teknologiset ongelmat materialisoituivat ennen kaikkea käytössä olleisiin mikrofoneihin, ja monet keskustelut keskittyivät mikrofonin siirtelyyn tai sen toimivuuden tarkasteluun. Osallistujat tuntuivat tunnistavan mikrofonin paitsi tilaan liittyvänä tekijänä, myös yhtenä toimijana. Ongelmia oli tosin muitakin: toisinaan etäosallistujat eivät saaneet videokuvaa seminaaritilasta. Myös selaimen tai tietokoneen päivitykset - tai lähinnä niiden puutteiden aiheuttamat ongelmat - olivat havaittavissa aineistosta.

Teknologian toimimattomuus vaikutti sekä fyysisesti läsnä oleviin osallistujiin että etäosallistujiin. Ensimmäinen seuraus oli klinikassa käytetty aika. Jos teknologian kuntoon saaminen vei aikaa, tämä oli luonnollisesti pois käsiteltävää tekstiä varten varatusta ajasta. Toinen seuraus oli klinikan sujuvuus: mikäli teknologiset ongelmat ilmaantuivat kesken klinikkatapaamisen, keskeytti se vuorovaikutusjärjestyksen ja keskittymisen käsiteltävään aiheeseen. Sujuvuuteen liittyi myös kolmas seuraus - viestintävälineen vaihto. Joskus etäosallistujaa itseään ei kuultu seminaaritilassa, jolloin etäosallistujan tuli vaihtaa viestintävälinettä mikrofonista AdobeConnectin chat-ikkunaan kirjoittamiseen. Tämä puolestaan hidasti vuorovaikutusta merkittävästi ja esti sujuvan ja nopean puhedialogin.

Kolmas teknologiaan liittyvien ongelmatilanteiden seuraus oli klinikkaan osallistumisen osittaisuus tai sen kokonainen estyminen. Esimerkiksi viestintävälineen vaihto puheesta chat-ikkunaan kirjoittamiseen hidasti ja vaikeutti etäosallistujien täysinäistä osallistumista. Tämä puolestaan vaikutti osallistumisen mielekkyyteen ja ulkopuolisuuden tunteiden heräämiseen, mikä tuli ilmi verkkokyselyn vastauksista. Tähän saattoi vaikuttaa myös se, ettei seminaaritilasta ollut aina saatavilla videokuvaa. Tällöin etäosallistujat joutuivat 
turvautumaan muiden osallistujien ääneen, eivätkä välttämättä aina tienneet, kenelle ääni kuului. Lisäksi harvoissa tilanteissa etäosallistuminen ei ollut lainkaan mahdollista, jos useista yrityksistä huolimatta mikrofoniyhteyttä seminaaritilasta etäosallistujien suuntaan ei saatu toimimaan. Kun ilman videokuvaa osallistuminen oli vielä osittain mahdollista, ilman ääntä siitä tuli täysin mahdotonta. Tämä taas johti siihen, että myös fyysiset osallistujat saivat vähemmän palautetta teksteistään.

\subsection{Toimijat}

Analyysista noussut toinen kategoria, toimijoihin liittyvät tekijät, sisälsi varsin monipuolisia syitä, jotka vuorovaikutusjärjestyksen lisäksi olivat vahvasti sidoksissa myös toimijahistorioihin, esimerkiksi osallistujien (tai mahdollisten osallistujien) henkilökohtaiseen tilanteeseen. Joko osallistujia ei ollut tarpeeksi (esim. potentiaalisten osallistujien muut kiireet, etäosallistuminen epämielekkyys, klinikan aihetta ei koettu relevantiksi oman työn kannalta) tai teknologiset ongelmat johtuivat inhimillisistä tekijöistä (esim. tekemättömät tietokoneen päivitykset). Nämä tekijät aiheuttivat osin samoja, osin erilaisia seurauksia kuin teknologian toimimattomuus. Esimerkiksi potentiaalisten osallistujien kiireet aiheuttivat sen, että klinikan osallistujamäärät vaihtelivat suuresti klinikkakerrasta riippuen muutamasta osallistujasta yli kymmeneen. Vaikka kaikki keskustelu ja palaute koettiin usein hyödylliseksi, verkkokyselyn tulokset osoittivat, että aktiivisempaa osallistumista klinikkaan olisi kaivattu:

"Mielestäni klinikka ei toimi yhtä hyvin ilman aktiivista osallistumista. Toivon, että useammat ihmiset voisivat osallistua, ja ne, jotka osallistuvat olisivat aktiivisempia (esim. kommentoimaan tai keskustelemaan)." (tohtoriopiskelija)
Osallistujien puute tai osallistujien epäaktiivisuus koettiin siis siten, ettei klinikasta saanut kaikkea sitä irti, mitä siitä olisi voinut mahdollisesti saada.

Toinen klinikan toimijoihin ja sen hyötyihin liittyvä tekijä oli se, ettei klinikassa käsiteltävää materiaalia jaettu muille Yammerissa riittävän ajoissa, jolloin muut osallistujat eivät ehtineet tutustua siihen kunnolla antaakseen klinikassa siitä kunnollista palautetta. Useimmiten materiaali kuitenkin jaettiin sovittua kahta päivää aikaisemmin, mutta palautetta ei valmisteltu kunnolla siitä huolimatta. Kuten huono mikrofonin toimivuus ja kuuluvuus etäosallistujille, myös tämä tekijä vaikutti klinikan hyödyllisyyteen ja mielekkyyteen:

"Kirjoitusklinikka onnistuu, jos a) kirjoittaja
on ehtinyt lähettää tekstin muille luettavaksi
ajoissa b) muut ovat ehtineet tutustua tekstiin.
Näiden kahden seikan puuttuminen luonnolli-
sesti on joskus aiheuttanut turhauttavia koke-
muksia." (tohtoriopiskelija)

Lisäksi osa verkkokyselyyn vastanneista oli sitä mieltä, että klinikkakerran kulkua ei välttämättä aina ohjailtu riittävästi: Verkkokyselyyn vastanneet antoivat palautetta siitä, että toisinaan yksittäisten ihmisten puheenvuorot olivat liian pitkiä, kun taas toiset saivat puhua liian vähän aikaa. Tyytymättömyyttä herätti siis sovittujen ja vakiintuneiden raamien puute:

"[E]hkä palautteen antamista voisi hieman ohjailla niin, että jokainen paikalla oleva ohjaaja (ja miksei opiskelijakin) antaa palautetta vain siitä tekstinosasta, jota juuri sillä hetkellä käsitellään, eikä siten, että yksi sanoo kaiken sanottavansa yhdellä kertaa. Silloin voi käydä niin, että muiden puheenvuorot jäävät tarpeettoman lyhyiksi." (tohtoriopiskelija)

"Yleinen keskustelu on joskus liian pitkä, eikä meillä ole tarpeeksi aikaa käsitellä varsinaista tekstiä, mikä on sääli.” (ohjaaja) 


\subsection{Kieli}

Viimeisenä laajempana kategoriana, joka aineistostamme nousi vuorovaikutusjärjestyksen häiriintymisen, mutta myös toimijahistorioiden näkökulmasta, oli klinikoiden aikana käytetty kieli. Koska Solkin ohjaajat ja tohtoriopiskelijat puhuvat useita eri kieliä äidinkielenään ja esimerkiksi englannin ja suomen taidot vaihtelevat suuresti, se aiheutti haasteita myös kirjoitusklinikan kielipolitiikkaan. Joko klinikassa käsitelty artikkeli oli kielellä, jota muut potentiaaliset osallistujat eivät ymmärtäneet eivätkä siten osallistuneet, tai klinikan aikana käytetystä kielestä ei neuvoteltu klinikan alussa, vaan sen sijaan kielen oletettiin olevan joko suomi tai englanti, koska käsitelty teksti oli näistä jommallakummalla kielellä.

Kieltä koskevat havainnot ja verkkokyselyn avoimet vastaukset olivat kaikista ristiriitaisimpia. Tätä havainnollistavat hyvin kaksi seuraavaa aineistonäytettä. Niistä ensimmäisessä kirjoittajalla on kaksi toivetta:

\footnotetext{
"Toivoisin myös, että kielipolitiikka olisi aidosti vapaa, ts. että englantia ja suomea voisi käyttää tasa-arvoisesti. Toivon myös, että erityisesti Suomesta ja [Jyväskylän yliopistosta] rahoitettavat tohtoriopiskelijat näkisivät sen vaivan, että opiskelisivat suomea edes auttavasti. Siitä on hyötyä heille itselleenkin viimeistään siinä vaiheessa, kun hakevat töitä Suomesta." (ohjaaja)
}

Ensiksi tämä vastaaja siis toivoi, että kielipolitiikka olisi "aidosti vapaa", jolla hän viittaa siihen, että klinikoiden aikana voisi käyttää vapaasti joko suomea tai englantia. Tähän klinikoissa pyrittiinkin lähettämällä esimerkiksi kaikki klinikkatapaamisia koskevat sähköpostit ja Yammer-viestit sekä suomeksi että englanniksi. Lisäksi klinikkatapaamisten aikana kuultiin usein sekä suomea että englantia. Kaiken puhutun kielen simultaani- tai konsekutiivitulkkaus ei kuitenkaan ollut mahdollista, viittomakieltä lukuun ottamatta. Sen sijaan klinikoiden alussa usein sovittiin, millä kielillä osallistujat halusivat toimia. Usein kuitenkin esimerkiksi käsiteltävän tekstin kieli oli rajannut osallistujat jo valmiiksi niin, etteivät esimerkiksi suomea puhumattomat tohtoriopiskelijat tai ohjaajat osallistuneet lainkaan sellaiseen klinikkaan, jossa käsiteltävän tekstin kieli oli suomi.

Toiseksi vastaaja toivoi, että ulkomaalaiset tohtoriopiskelijat, jotka saavat rahoituksensa suomalaisesta lähteestä, opiskelisivat suomea edes auttavasti, koska siitä olisi hyötyä heille myös tulevaisuuden kannalta. Tämä ei kuitenkaan ollut kaikkien vastaajien mielestä riittävää tutkimukseen liittyvän keskustelun näkökulmasta, kuten käy ilmi alla olevasta verkkokyselyn vastauksesta. Tämän vastaajan mielestä vain omalla äidinkielellä (joka tässä tapauksessa on suomi) on mahdollista selittää riittävän tarkasti, mistä tutkimuksessa tai sen eri käsitteissä on kyse:

”Ymmärrän, että englanniksi tulee pystyä
keskustelemaan/ esittämään/ perustelemaan,
mutta jokainen meistä tietää, että esimerkiksi
käsitteistön selittäminen toisella kielellä on
melko haastavaa (kun se voi olla vaikeaa myös
suomeksi), etenkin niin, että tulee varmasti
oikein ymmärretyksi. Se toisinaan turhauttaa,
että jää aina vähän epäselväksi, että meniköhän
ihan oikein kaikki. Mielestäni omalla äidin-
kielellä tulee olla oikeus tulla kuulluksi ilman,
että joudut sitä kovasti penäämään. Syvälliseen
keskusteluun pystyy vain omalla kielellä." (toh-
toriopiskelija)

Näiden esimerkkien sekä aineistosta löytyvien muiden kieleen liittyvien ongelmatilanteiden perusteella voidaankin siis todeta, että teknologiaan ja toimijoihin liittyvien ongelmatilanteiden ohella myös kieli voi joko rajoittaa kirjoitusklinikkaan osallistumista tai jopa kokonaan estää sen. Tämä 
tietysti vähentää klinikkaan osallistuvien tohtoriopiskelijoiden, ohjaajien ja sitä kautta käsiteltävästä tekstistä saadun palautteen määrää.

\section{POHDINTA}

Ymmärtääksemme analyysimme perusteella nousseita kolmea kategoriaa paremmin, meidän on palattava Goffmanin (1983) vuorovaikutusjärjestyksen määritelmään, eli siihen, miten vuorovaikutus tietyssä tilanteessa järjestäytyy ja miten tilanteen toimijat sen eri tilanteissa luovat. Pohtiaksemme tuloksia tästä näkökulmasta, meidän on kuitenkin ensin pohdittava sitä, mitä Solkin kirjoitusklinikan normit tai toimijoiden kulttuuriset odotukset sekä kokemukset ovat, ja mistä ne kumpuavat.

Kirjoitusklinikkatoiminta alkoi vuonna 2014, joten sen käytännöt olivat vakiintuneet siihen mennessä, kun tämän tutkimuksen aineisto kerättiin vuosina 2016 ja 2017 . Käytännöistä olivat sopineet klinikan järjestäjät, jotka viestivät käytännöistä klinikan osallistujille joko sähköpostitse tai klinikan aikana. Pikkuhiljaa nämä kirjoittamattomat ja kirjoitetut normit olivat tulleet tutuiksi niille, jotka osallistuivat klinikkaan säännöllisesti. Toisin kuin tekstien lähettäminen ajoissa ja niihin ennalta tutustuminen, mikä oli klinikkaan osallistujien sopima ja yleisessä tiedossa oleva sääntö, klinikan aikana tapahtuvan keskustelun rakenteesta ja puheenvuorojen pituudesta sen sijaan ei ollut virallisesti sovittu. Jokaisella klinikkakerralla oli yksi puheenjohtaja, joka ohjasi keskustelua. Kuten analyysimme toimijoita koskevassa osiossa tulikin ilmi, verkkokyselyn perusteella vaikutti siltä, että myös itse keskustelun vuorovaikutusjärjestyksestä olisi pitänyt sopia etukäteen tarkemmin. Lisäksi jotkut sovitut normit, kuten klinikan aikana käytetystä kielestä sopiminen, eivät aina toteutuneet: kieleksi esimerkiksi oletettiin suomi eikä siitä keskusteltu, mikäli fyysises- ti paikalla oli vain oletettavasti syntyperäisiä suomalaisia.

Toisinaan joku osallistuja oli paikalla ensimmäistä kertaa. Tämä näkyi yleensä niin, ettei esimerkiksi hiljattain aloittanut tohtoriopiskelija ollut paljoa äänessä klinikan aikana, vaan sen sijaan tarkkailijan roolissa - tutustumassa olemassa oleviin normeihin. Joskus ensikertalainen ilmaisi avoimesti olevansa klinikassa ensimmäistä kertaa. Vaikka ensimmäistä kertaa osallistuva olisi ollut aiemmin mukana erilaisissa kirjoitustyöpajoissa tai klinikkatoimintaa vastaavissa tilaisuuksissa, ei hänellä kuitenkaan voinut olla täyttä varmuutta siitä, miten juuri Solkin kirjoitusklinikassa toimitaan. Siksi klinikan normien voidaan sanoa olevan uniikkeja tai ainakin osittain tuntemattomia heille, jotka eivät ole aiemmin osallistuneet. Ensi kertaa osallistuvilla saattaa kuitenkin olla odotuksia klinikkaan liittyen: ehkä he ovat kuulleet klinikasta muilta, jotka ovat aiemmin osallistuneet. Vastaavasti he saattavat olettaa, että klinikassa toimitaan samalla tavalla kuin tilaisuudessa, johon he ovat aikaisemmin osallistuneet muussa yhteydessä.

Solkin kirjoitusklinikoiden vuorovaikutusjärjestykseen liittyvät ongelmat olivat siis hyvin moninaisia, mutta myös vahvasti kytköksissä paikan diskursseibin (käytössä olleeseen teknologiaan, tilajärjestelyihin, sekä paikkakohtaisiin osallistumisen käytänteisiin) ja osallistujien toimijahistorioibin (aiemmat klinikkakokemukset, teknologinen osaaminen, kielitaito, akateeminen kokemus ja rooli tilanteessa). Selventääksemme tätä nostamme seuraavaksi esiin kaksi erityisen mielenkiintoista tuloksista noussutta havaintoa.

\subsection{Toiminnan materialisoituminen mikrofonissa}

Mikäli tarkastelemme vuorovaikutusjärjestystä nimenomaan Scollonin ja Scollonin (2004) neksusanalyysin näkökulmasta, on 
meidän otettava mukaan teknologinen ulottuvuus. Scollonien mukaan teknologia nimittäin mahdollistaa kaiken sosiaalisen toiminnan tai ainakin tukee sitä, joskin teknologia voi viitata myös hyvin yksinkertaisiin välineisiin, kuten paperiin ja kynään. Voidaan ajatella, että perinteinen seminaarityöskentely on tohtoriopiskelijoille huomattavasti tutumpaa, koska erilaiset etäosallistumisen mahdollisuudet ovat yleistyneet vasta viime vuosien aikana (sekä korkeakoulukontekstissa että muussa viestinnässä). Tämän vuoksi klinikan normit ja odotukset eivät koskeneet ainoastaan sitä, miten seminaaritilassa toimitaan, vaan myös sitä, miten osallistumiseen tarvittavia sovelluksia (Yammer, AdobeConnect) käytetään. Toisin sanoen, vaikka osallistuja olisi ollut mukana kymmenissä eri seminaareissa, hän ei välttämättä ollut aiemmin käyttänyt Yammeria tai AdobeConnectia.

Teknologinen ulottuvuus (etäosallistuminen sekä siihen käytetyt ohjelmat) haastoi vuorovaikutusjärjestyksen esimerkiksi siten, että etäosallistujien chat-viestit tai kommentit kaiuttimien kautta rikkoivat totuttua seminaarin vuorovaikutusjärjestystä: Mikäli etäosallistujia ei esimerkiksi ollut, klinikan järjestäjä (senioritutkija) jakoi puheenvuoroja vuorotellen heille, jotka ilmaisivat halunsa kommentoida tai kysyä jotakin tekstin kirjoittajalta esimerkiksi viittaamalla. Jos etäosallistujia sen sijaan oli, puheenvuorossa ollut osallistuja sai käteensä kiertävän mikrofonin, joka toimi näin siis merkkinä puheenvuoron saamisesta. Etäosallistujat puolestaan ilmaisivat halunsa kommentoida chat-viestillä, joka ilmestyi näkyviin sekä ylläpitäjän edessä olevalle tietokoneelle että seminaaritilan seinällä olevalle valkokankaalle. Tästä huolimatta viestiä ei aina välttämättä huomattu välittömästi, ja klinikan järjestäjä kommentoi johonkin väliin, että tietyllä etäosallistujalla on jotakin sanottavaa. Toisinaan etäosallistujan kysymys tai kommentti saattoi näkyä Ado-
beConnectin chat-ikkunassa melko pitkään, ennen kuin se huomattiin.

Tällä tavoin seminaaritilassa olevat osallistujat olivat vuorovaikutusjärjestyshierarkiassa ikään kuin ensimmäisinä. Toissijaiseksi toimijaksi jääminen saattaa etäosallistujien kohdalla mitätöidä sitä positiivista vaikutusta, mikä Boudin ja Leen (2005), Maherin ym. (2008) sekä Parkerin (2009) tutkimuksissa on todettu kasvokkaisilla kirjoitusryhmillä olevan tutkijayhteisöön kuulumisen kokemisessa. Koska mikrofoni ja sen käyttöä säätelevät klinikan järjestäjät olivat avainasemassa siinä, kenellä puheenvuoro oli, voidaan siis sanoa, että klinikan vuorovaikutusjärjestys ja toiminta materialisoituivat laajalti mikrofonissa. Ilman mikrofonia etäosallistujat eivät kuulleet, mitä seminaaritilan osallistujat puhuivat, ja mikrofonin toimimattomuus johti siihen, etteivät etäosallistujat voineet osallistua toimintaan. Esimerkiksi videokuvan rooli ei ollut verrattavissa tähän, sillä ilman videokuvaa etäosallistuminen vielä onnistui.

Vaikka mikrofonin merkitys oli suuri, on kuitenkin huomioitava, että vuorovaikutusjärjestykseen vaikuttivat myös toimijahistorialliset tekijät, kuten osallistujan asema akateemisessa yhteisössä. Usein esimerkiksi ohjaajat aloittivat kommentoimisen, ja vasta heidän jälkeensä tohtoriopiskelijat uskaltautuivat kommentoimaan - ensin pidemmällä olevat opiskelijat, ja vasta lopuksi aloittelevat opiskelijat, joskaan he eivät aina kommentoineet lainkaan. Tämä puolestaan osoittaa sen, miten erilaisilla yliopiston valtasuhteilla on merkitystä niissäkin tilanteissa, joissa osallistujia kannustetaan avoimeen keskusteluun ja vertaispalautteen antamiseen. 


\subsection{Millä kielellä tutkimuksesta voi/ pitäisi pubua?}

Kieleen liittyvien tekijöiden analyysistä nousi esiin ristiriitaisia näkemyksiä liittyen siihen, millä kielellä klinikan osallistujien tulisi pystyä toimimaan. Kun eräs vastaaja toivoi, että kansainväliset tohtoriopiskelijat opiskelisivat suomea ainakin auttavasti, toinen oli sitä mieltä, että vain omalla äidinkielellä pystyy puhumaan omasta tutkimuksestaan tarpeeksi hyvin. Mikäli ajatellaan, että tämä koskisi kaikkia opiskelijoita, vastaan tulevat kuitenkin opiskeluyhteisön kielitaidon rajat: millä kielellä kirjoitusklinikoissa on ylipäätään mahdollista keskustella tutkimuksesta? Tulisiko sen olla suomi, koska kyseessä on suomalainen yliopisto? Vai tulisiko sen olla englanti, koska englanti on se kieli, jota useimmat tohtoriopiskelijat ja ohjaajat osaavat ainakin hieman? Entä, jos tohtoriopiskelijan äidinkieli on jokin muu kuin suomi tai englanti?

Toisaalta voidaan myös kysyä, onko hyväksyttävää, etteivät kaikki tohtoriopiskelijat voi osallistua tiettyyn klinikkaan siksi, etteivät he mielestään osaa tarpeeksi klinikassa käytettyä kieltä. Lisäksi voidaan pohtia, voisivatko kaikki tohtoriopiskelijat ainakin joskus puhua omasta tutkimuksestaan tai antaa palautetta muiden tutkimuksesta omalla äidinkielellään (esimerkiksi suomeksi) tai vastaavasti sillä kielellä, joka itselle ei ole niin vahva (esimerkiksi englanniksi). Monikieliseen viestintään liittyvät osaamistavoitteet on esimerkiksi kirjattu Jyväskylän yliopiston humanistis-yhteiskuntatieteellisen tiedekunnan jatko-opintosuunnitelmaan, jonka mukaan tohtoriopiskelijoiden tulee pystyä "esittelemään omaa tutkimustaan suullisesti ja kirjallisesti kansainväliselle yleisölle". Lisäksi suunnitelmaan on kirjattu osaamistavoite tohtorikoulutettaville, joiden äidinkieli on jokin muu kuin suomi: "kielitaitonsa lähtötilanteesta riippuen joko selviytyy arkipäiväisistä kielenkäyttötilanteis- ta suomeksi tai pystyy puhumaan ja kirjoittamaan myös omasta tutkimuksestaan suomeksi” (Jyväskylän yliopisto, 2017).

On selvää, että monikielisessä ympäristössä toimiminen luo haasteita erilaisten tapahtumien ja muiden vuorovaikutustilanteiden kielivalintaan. Etenkin tutkitussa kontekstissa, jossa tohtoriopiskelijat tulevat useasta eri maasta ja puhuvat äidinkielenään monia eri kieliä, kieleen liittyvät kysymykset saattavat nousta esiin normaalia voimakkaammin. Tämän vuoksi käytettävästä kielestä neuvottelu ennen jokaista klinikkakertaa olisikin ensisijaisen tärkeää, ja käytetystä kielestä tulisi pystyä puhumaan avoimesti.

\section{LOPUKSI: MUUTOS JA KRIITTISYYS}

Tässä artikkelissa käsittelimme neksusanalyyttisen viitekehyksen avulla sitä, millaiset tekijät mahdollistavat ja rajaavat tohtoriopiskelijoiden osallistumista monikanavaiseen tohtoriseminaariin. Tunnistimme kolme laajempaa kategoriaa näihin tekijöihin liittyen: teknologiaan, toimijoihin ja kieleen liittyvät tekijät. Osa näistä on linjassa aiemman tutkimuskirjallisuuden kanssa, jonka mukaan videokonferenssin onnistuminen vaatii riittävää valmistautumista, aikaa sekä rahallisia resursseja (Andrews \& Klease, 1998; Dogget, 2008). Lisäksi tutkimme, miten näihin tekijöihin liittyvät ongelmatilanteet vaikuttivat tutkittavaan kontekstiin - Solkin kirjoitusklinikkaan. Vaikutukset tutkittuun toimintaan olivat kolmessa tunnistetussa kategoriassa hyvin samankaltaiset. Ongelmatilanteet veivät aikaa pois käsiteltävältä asialta (teknologia), vaikeuttivat osallistumista (teknologia, kieli), estivät sen kokonaan (teknologia, toimijat, kieli), vaikuttivat osallistumisen mielekkyyteen (teknologia, toimijat, kieli) tai koettuun hyödyllisyyteen (toimijat) ja aiheuttivat muita negatiivisia tuntemuksia osallistujissa, 
kuten esimerkiksi turhautumista (teknologia, toimijat) tai kriittisyyttä muiden käyttämää kieltä kohtaan (kieli).

Kuten kaikkeen soveltavaan tutkimukseen (ja joskus myös perustutkimukseen, ks. Stokes, 1997), myös neksusanalyysin kauaskantoisempiin tavoitteisiin kuuluu tärkeänä osana muutos (Scollon \& Scollon, 2004). Muutosta voidaan saada aikaan usealla eri tavalla. Näistä ensimmäinen on tehdä systemaattista tutkimusta liittyen siihen laajempaan toiminnan neksukseen, josta tutkija on kiinnostunut. Näin tutkittavasta toiminnasta voidaan saada yhä enemmän tietoa ja sitä voidaan ymmärtää paremmin. Esimerkiksi tämä tutkimus on osa laajempaa, tohtoriopintoja koskevaa neksusanalyysiä, johon liittyy kolme muuta osatutkimusta.

Neksusanalyysiin liittyvä muutos voi myös sisältää pienempiä konkreettisia toimia, jotka vähitellen johtavat mahdollisesti laajempaan muutokseen. Tämän tutkimuksen kohdalla muutos on sisältänyt useita, pienempiä askeleita. Ensimmäinen näistä oli verkkokyselyssä esille tulleiden kehitysehdotusten käsittely. Kyselyssä vastaajat saivat ehdottaa, millaisia teemoja he toivoisivat klinikassa jatkossa käsiteltävän. Aarnikoivu kokosi nämä yhtenäiseksi listaksi ja toimitti sen sähköpostitse kirjoitusklinikan silloisille järjestäjille. Toinen toimi oli esitellä tämän tutkimuksen alustavia tuloksia Solkin tohtoriopiskelijoille järjestetyssä jatko-opintoseminaarissa marraskuussa 2018. Seminaariin osallistui sekä tohtoriopiskelijoita että ohjaajia, ja esitelmä herätti aktiivista keskustelua. Vuonna 2018 Solki myös hankki kädessä pidettävien mikrofonien tilalle pöytämikrofonin, jonka käyttöönoton jälkeen suurin osa ääniyhteyteen liittyvistä ongelmista poistui. Toistaiseksi viimeinen konkreettinen muutos koskee klinikkatoiminnan levittämistä laajemmalle. Ongelmatilanteista huolimatta sekä verkkokyselyn vastauksista että kirjoitusklinikoiden aikana tehdyistä havainnoista nousi esille, kuinka hyödyllinen kirjoittamisopetuksen muoto kirjoitusklinikka sen osallistujille on. Tästä inspiroituneena Aarnikoivu ehdotti Solkin kirjoitusklinikoiden kaltaista tapahtumaa järjestettäväksi nuorille korkeakoulututkijoille Saksan Kasselissa elokuussa 2019³. Klinikkaan osallistui 23 nuorta korkeakoulututkijaa ympäri maailmaa, ja tarkoituksena on järjestää samankaltainen tapahtuma Kroatian Rijekassa vuonna 2020.

Viimeinen, ehkäpä tärkein muutoskeino on muodostaa ja kysyä yhä parempia kysymyksiä kuin aiemmin sen sijaan, että etsittäisiin vastauksia tiettyihin, ennalta esitettyihin kysymyksiin (Scollon \& Scollon, 2004). Vaikka tässä artikkelissa etsimmekin vastauksia kahteen tarkasti määriteltyyn tutkimuskysymykseen, voi tämän tutkimuksen perusteella myös esittää tärkeitä jatkokysymyksiä ohjaamaan tulevaa tutkimusta sekä laitos-, tiedekunta- ja yliopistotason päätöksentekoa. Tämän tutkimuksen perusteella esitämmekin seuraavat kysymykset: miten osallistujien toimijahistoriat (aiemmat klinikkakokemukset, teknologinen osaaminen, kielitaito) olisi mahdollista huomioida paremmin tohtoriseminaaritoimintaa suunniteltaessa? Ketkä kirjoitusklinikoihin ylipäätään osallistuvat ja miksi juuri he? Ketkä osallistumisesta päättävät ja miksi juuri he? Ketkä klinikan aikana käytetystä kielestä päättävät, ja miksi juuri he?

Vaikka omaan instituutioon liittyvien kriittisten kysymysten kysyminen ei usein ole helppoa, se on kuitenkin välttämätöntä positiivisen muutoksen aikaansaamiseksi (Mahon, Heikkinen \& Huttunen, 2018). Kriittisyyden vastapainona lienee kuitenkin aiheellista myös huomioida tietyn toiminnan onnistuneet puolet: etäosallistumismahdollisuuden tarjoamalla Solkin kirjoitusklinik-

\footnotetext{
3 Tapahtuman järjesti uransa alkuvaiheessa olevien nuorten korkeakoulututkijoiden verkosto ECHER (early-career higher education researchers). ECHERin verkkosivu: http://www.echer.org
} 
katoiminta myös pyrki rikkomaan niitä ajan ja paikan rajoitteita, joita kirjoituksen opetukseen on tutkittu sisältyvän (ks. Lassig ym., 2013; Maher ym., 2013; Svinhufvud, 2014). Tällainen aikaa ja paikkaa haastava toiminta ja sen analyysi voi auttaa kyseenalaistamaan

\section{LÄHTEET}

Allen, M., Bourhis, J., Burrell, N. \& Mabry, E. (2002). Comparing student satisfaction with distance education to traditional classrooms in higher education: a meta-analysis. American Journal of Distance Education, 16, 83-97.

Andrews, T. \& Klease, G. (1998). Challenges of multisite video conferencing: The development of an alternative teaching/learning model. Australasian Journal of Educational Technology, 14, 88-97.

Boud, D. \& Lee, A. (2005). Peer learning as pedagogic discourse for research education. Studies in Higher Education, 30, 501-15.

Çakıroğlu, Ü., Kokoç, M., Kol, E. \& Turan, E. (2016). Exploring teaching programming online through web conferencing system: The lens of activity theory. Journal of Educational Technology \& Society, 19, 126-139.

Candarli, D. \& Yuksel, H. G. (2012). Students' perceptions of video-conferencing in the classrooms in higher education. Procedia - Social and Behavioral Sciences, 47,357-361.

Candela, L., Carver, L., Diaz, A., Edmunds, J., Talusan, R. \& Tarrant, T. A. (2009). An online doctoral education course using problem-based learning. The Journal of Nursing Education, 48, 116-119.

Cotterall, S. (2011). Doctoral students writing: where's the pedagogy? Teaching in Higher Education, 16, 413-425.

Delyser, D. (2003). Teaching graduate students to write: a seminar for thesis and dissertation writers. Journal of Geography in Higher Education, 27, 169-181.

Doggett, A. M. (2007). The videoconferencing classroom: What do students think? Journal of Industrial Teacher Education, 44, 29-41. myös muita tohtorikoulutuksen itsestään selvinä pidettyjä elementtejä. Lisäksi oman toiminnan analyysi on hedelmällistä itsereflektiota, mutta antaa toivottavasti reflektion lähtökohtia myös tätä artikkelia lukeville.

Ferguson, T. (2009). The "write" skills and more: A thesis writing group for doctoral students. Journal of Geography in Higher Education, 33, 285-297.

Gillies, D. (2008). Student perspectives on videoconferencing in teacher education at a distance. Distance Education, 29, 107-118.

Goffman, E. (1983). The interaction order. American Sociological Review, 48, 1-17.

Henriksen, D., Mishra, P., Greenhow, C., Cain, W., Roseth, C. (2014). A tale of two courses: Innovation in the hybrid/online doctoral program at Michigan State University. TechTrends, 58, 45-53.

Hsieh, H.-F. \& Shannon, S. E. (2005). Three approaches to qualitative content analysis. Qualitative Health Research, 15, 1277-88.

Johnson, E. (2014). Toward the building of a cross-disciplinary doctoral research and writing culture. Journal of University Teaching \& Learning Practice, 11.

Jones, R. \& Norris, S. (2005). Discourse as action/ discourse in action. Teoksessa S. Norris \& R. Jones (toim.), Discourse in action: Introducing mediated discourse analysis, (s. 3-14). London: Routledge.

Jyväskylän yliopisto. 2017. Humanistisyhteiskuntatieteellisen tiedekunnan jatkoopetussuunnitelma 1.4.2017-31.7.2020. Haettu 17.6.2019 osoitteesta https://www. jyu.fi/hytk/fi/tutkimus/tohtorikoulutus/ tutkintovatimukset/humanistisyhteiskuntatieteellisen-tiedekunnan-jatkoopetussuunnitelma

Kamler, B. \& Thomson, P. (2006). Doctoral writing: pedagogies for work with literatures. Esitelmä: AERA annual meeting, doctoral writing symposium, huhtikuu 2006, San Francisco, Yhdysvallat. 
Kamler, B. (2008). Rethinking doctoral publication practices: writing from and beyond the thesis. Studies in Higher Education, 33, 283-294.

Karjalainen, R. 2015. Saamen kielet pääomana monikielisellä Skábmagovat-elokuvafestivaalilla. Väitöskirja. Jyväskylä Studies in Humanities 254. Jyväskylä: Jyväskylän yliopisto.

Kaufmann, R. \& Frisby, B. N. (2013). Let's connect: using Adobe Connect to foster group collaboration in the online classroom. Communication Teacher, 27, 230-234.

Kress, G. (2010). Multimodal discourse analysis. Teoksessa J. P. Gee and M. Handford (toim.), The Routledge Handbook of Discourse Analysis, (s. 35-50). London: Routledge.

Lassig, C. J., Dillon, L. H. \& Diezmann, C. M. (2013). Student or scholar? Transforming identities through a research writing group. Studies in Continuing Education, 35, 299-314.

Lee, A. \& Boud, D. (2003). Writing groups, change and academic identity: Research development as local practice. Studies in Higher Education, 28, 187-200.

Lehtinen, E. \& Nummenmaa, M. (2012). Etä-opetuksen lumo: Kansainvälinen kirjallisuuskatsaus. Turku: Turun yliopisto.

Maher, D., Seaton, L., McMullen, C., Fitzgerald, T., Otsuji, E. \& Lee, A. (2008). Becoming and being writers: The experiences of doctoral students in writing groups. Studies in Continuing Education, 30, 263-275.

Maher, M., Fallucca, A. \& Halasz, H. M. (2013). Write on! Through to the Ph.D.: Using writing groups to facilitate doctoral degree progress. Studies in Continuing Education, 35, 193-208.

Mahon, K., Heikkinen, H. L. \& Huttunen, R. (2018). Critical educational praxis in university ecosystems: enablers and constraints. Pedagogy, Culture and Society, 27, 460-480.

Martin, S. (2005). Seeing is believing: The role of videoconferencing in distance learning. British Journal of Educational Technology, 36, 397-405.

Mayring, P. (2000). Qualitative Content Analysis [28 paragraphs]. Forum Qualitative

Sozialforschung [Forum: Qualitative Social Research] 1(2), Art. 20. Haettu 29.3.2018 osoitteesta http://nbnresolving.de/ urn:nbn:de:0114-fqs0002204
Messina Dahlberg, G. \& Bagga-Gupta, S. (2014). Understanding glocal learning spaces. An empirical study of languaging and transmigrant positions in the virtual classroom. Learning, Media and Technology, 39, 468-487.

Morss, K. \& Murray, R. (2001). Researching academic writing within a structured programme: insights and outcomes. Studies in Higher Education, 26, 35-52.

Murray, R. (2001). Integrating teaching and research through writing development for students and staff. Active Learning in Higher Education, 2, 31-45.

Norris, S. \& Jones, R. (toim.) (2005). Discourse in action: Introducing mediated discourse analysis. London: Routledge.

Parker, R. (2009). A learning community approach to doctoral education in the social sciences. Teaching in Higher Education, 14, 43-54.

Penuel, W.R. \& Wertsch, J.V. (1995). Dynamics of negation in the identity politics of cultural other and cultural self. Culture and Psychology, $1,343-359$.

Piattoeva, N. (2016). Kirjoittaminen taitona, velvollisuutena ja oikeutena. Tieteessä tapahtuu, 3,61 .

Pietikäinen, S. (2012). Kieli-ideologiat arjessa. Neksusanalyysi monikielisen inarinsaamenpuhujan kielielämäkerrasta. Virittäjä, 3, 410-442.

Rautiainen-Keskustalo, T., Raudaskoski, S., Colliander, M., Pimiä, A., Rantanen, A. \& Teikari, A. (2014). Moniaineksinen etäkonsertti: Neksusanalyysi musiikillisen toiminnan tutkimusmetodina. Musiikki, 44, 6-28.

Roseth, C., Akcaoglu, M. \& Zellner, A. (2013). Blending synchronous face-to-face and computer-supported cooperative learning in a hybrid doctoral seminar. TechTrends, 57,54-59.

Scollon, R. (2001). Mediated discourse: The nexus of practice. London: Routledge.

Scollon, R. \& Scollon, S. W. (2004). Nexus Analysis: Discourse and the emerging internet. London, UK: Routledge.

Scollon, R. \& Scollon, S. W. (2007). Nexus analysis: Refocusing ethnography on action. Journal of Sociolinguistics, 11, 608-625. 
Stokes, D. E. (1997). Pasteur's quadrant: Basic science and technological innovation. Brookings Institution Press, Washington, D.C.

Strömmer, M. (2017). Mahdollisuuksien rajoissa. Neksusanalyysi suomen kielen oppimisesta siivoustyössä. Väitöskirja. Jyväskylä Studies in Humanities 336. Jyväskylä: Jyväskylän yliopisto.

Svinhufvud, K. (2014). Participation in the master's thesis seminar. Exploring the lack of discussion. Learning Culture and Social Interaction, 5, 66-83.

Virtanen, A. (2017). Toimijuutta toisella kielellä. Kansainvälisten sairaanhoitajaopiskelijoiden ammatillinen suomen kielen taito ja sen kebittyminen työharjoitteluissa. Väitöskirja. Jyväskylä Studies in Humanities 311. Jyväskylä: Jyväskylän yliopisto.

Vygotsky, L.S. (1978). Mind in Society: The development of higherpsychological processes. Cambridge, MA: Harvard University Press.

Vygotsky, L.S. (1987). The Collected Works of L.S. Vygotsky. Volume 1. Problems of general psychology. Including the Volume Thinking and Speech, toimittanut ja kääntänyt N. Minick. New York: Plenum.

Wang, C. X., Jaeger, D., Liu, J., Guo, X. \& Xie, N. (2013). Using synchronous technology to enrich student learning. TechTrends, 57, 20-25.

Wertsch, J.V. (1991). Voices of the Mind: A sociocultural approach to mediated action. Cambridge, MA: Harvard University Press.

Wertsch, J.V. (1995). Mediated action and the study of communication: The lessons of L. S. Vygotsky and M. M. Bakhtin. The Communication Review, 1, 133-154.

Wertsch, J.V. (1998). Mind as Action. New York: Oxford University Press.

Zhao, Y., Lei, J., Yan, B., Lai, C. \& Tan, H. S. (2005). What makes the difference? A practical analysis of research on the effectiveness of distance education. Teachers College Records, 107, 1836-84. 


\section{DISRUPTIONS OF HYBRID DOCTORAL SEMINARS: A NEXUS ANALYSIS}

Melina Aarnikoivu, Centre for Applied Language Studies, University of Jyväskylä

Taina Saarinen, Finnish Institute for Educational Research, University of Jyväskylä

In this study we explored what kind of disruptions there were involved in hybrid doctoral seminars. Furthermore, we examined what kind of consequences such disruptions had. As our theoretical-methodological framework we used nexus analysis (Scollon and Scollon 2004). The data comprised ethnographic field notes which were generated during "writing clinics" organised for doctoral students, the AdobeConnect chat discussions that took place during the clinics, Yammer discussions concerning the clinics, as well as the results of an online survey, which was sent to doctoral students and supervisors. Based on our analysis, we recognised three categories, which the disruptions were related to: technology, actors, and language. The disruptions took time away from the actual content, made participation in the writing clinic meetings more difficult or impossible, had a negative effect on the satisfaction towards participation, made the clinics feel less useful for participants, and were a source of other negative feelings among participants. The study and its results shift the attention towards what happens when a desired or expected mediated social action is disrupted for one reason or another, and thus helps to plan how hybrid seminars could be developed in the context of doctoral education, specifically, and in university teaching more generally.

Keywords: doctoral studies, hybrid seminar, interaction order, nexus analysis 